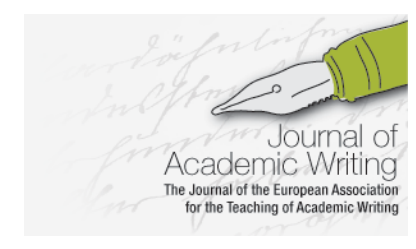

Journal of Academic Writing Vol. 7 No 1 Summer 2017, pages 59-62 http://dx.doi.org/10.18552/joaw.v7i1.402

\title{
Review of Writing Your Master's Thesis: From A to Zen
}

\author{
Kristin Solli \\ Oslo and Akershus University College of Applied Sciences, Norway
}

\author{
Nygaard, Lynn P. (2017) Writing Your Master's Thesis: From A to Zen. London: \\ Sage, pp. 224, £22.99, ISBN: 9781473903937
}

Do we need another book offering advice on academic writing? Given the vast number of 'howto-books' available, one would now think that a handbook exists for every potential genre, discipline, and academic level. Indeed, there is good reason to ask what the thriving advice book industry tells us about the place of writing in academia. On the one hand, the market for these books might be an indication of a growing interest in the place of writing in higher education. On the other, the popularity of these books could be a symptom of a more worrying situation. In an article that analyzes writing advice books for PhD students, Barbara Kamler and Pat Thomson ask whether the market for this genre is driven by structural conditions that relegate writing to arenas outside of class rooms and supervisory situations: 'Are our students now buying books because their advisors have less time and are more focused on doctoral completion rates?' (2008: 509)

Nigel Harwood and Bojana Petrić's recent study of Masters supervision from the perspectives of both students and supervisors, suggests that there might be good reason to ask the same question at Masters level. Their study reveals great variation in supervisory practices. While some students are offered useful and constructive support, others receive very little guidance from their supervisors. Petrić and Harwood point out that while variation in supervisory experiences and practices is to be expected, the findings of their study show 'inconsistency to a disturbing degree' (2017: 195). This inconsistency might help explain why some students turn to advice books for guidance. At least, it suggests that there are many students and supervisors who could make use of extra resources and materials in the thesis-writing process.

The proliferation of writing advice books should compel writing teachers and researchers to take such books seriously and engage with what they have to say. Kamler and Thomson's analysis of 25 advice books on writing for PhD students paints a dire picture. They conclude that the 'advice books offer reductive tips and tricks, couched in a paternalistic, instructional style. They prescribe a structure for the dissertation and a set of linear rules to follow' (2008: 512). Ultimately, they argue, the problem with such books is that 'they ossify doctoral research and the dissertation to formulaic axioms that ultimately serve to bolster a this-is-how-you-do-it position' (2008: 513).

My sense is that, like Kamler and Thomson, quite a few of us who teach writing find the prescriptive approaches permeating many advice books highly problematic. In my own teaching practices, I certainly struggle to find ways to help students navigate conventions while also retaining a sense of agency. Students sometimes tend to gravitate towards resources that provide lists and rules, and discussions about why such rules might not always be helpful are usually good teaching moments. Fortunately, there are now several advice books on the market that themselves point to what might be problematic aspects of thinking of writing as a set of seemingly transparent 'how-to' rules. For examples of such work, see Kamler and Thomson's own advice book, Helping Doctoral Students Write: Strategies for Supervision (2014) or Joseph Harris's Rewriting: How to Do Things with Texts (2007). I add Lynn P. Nygaard's Writing Your Master's Thesis: From A to Zen to this list of more self-aware advice books. 
At first glance, the title of Nygaard's book seems to offer rules of a rather predictable sort: a prescribed set of steps, from first to last. In the preface, however, Nygaard insists that the title is not meant to be understood in this way. Instead, she says, the title 'refers to the process of moving away from thinking of academic writing as a list of rules you have to follow ( $a, b$, then c) and towards developing such a good understanding of the purpose of writing your thesis that rules become superfluous' (2017: xv). A state in which rules are superfluous is, then, Nygaard's 'zen'. This is a rather lofty goal, yet it is a compelling one. And though I suspect that many students - even after reading this book - will not reach 'zen', the book is quite successful in what it sets out to do: rather than providing rules for getting the job done, it focuses on helping the reader understand the task at hand, or as Nygaard puts it ' why we do things the way we do' (2017: 3).

The book is structured in two parts. The first part is called 'The Process', and covers such topics as 'From topic to question to design', 'Ethics', 'Reading as thinking', 'Writing as thinking' and 'Supervision and guidance'. The second part, called 'The Product', addresses the thesis as text and follows a quite traditional structure: 'Structure and argument', 'Your introduction', 'Your theoretical and conceptual framework', 'Your method' and so on. Each chapter is followed by a set of questions for further reflection that are intended to help readers adapt the material to their own writing projects and contexts. There are also annotated lists of suggestions for further reading. Each chapter includes several vignettes, which illustrate how five fictional students from different disciplinary and language backgrounds approached various challenges in the thesis process.

The book is quite conventional in both structure and in topics addressed. It is the way Nygaard explicates these familiar topics that makes her approach more interesting and, ultimately, more useful than many standard advice books. One of the book's greatest strengths is that it neither promises nor offers any quick fixes. 'I'm not promising that reading this book will make writing your thesis easier', Nygaard warns in her preface, with refreshing honesty (2017: xvi). In fact, a recurring theme in the book is that writers might not always know exactly what they are doing or where they are going. And that this is normal. Finding writing messy and difficult, Nygaard maintains, is not the same as being a 'bad writer'. Instead, she says, what often distinguishes more experienced writers from less experienced writers is that experienced writers keep on writing 'even if they don't like what they are writing in that particular moment' (2017: 64). The rest of the chapter entitled, 'Writing as thinking', offers strategies for how writers might keep on writing during the times when they are unhappy about what appears on the page.

This portrayal of writing as messy, non-linear and unpredictable might in part stem from the fact that Nygaard was writing this book while writing her own PhD dissertation. The preface quite humorously describes moments of cognitive dissonance that many of us who teach writing will recognize: offering advice about writing does not necessarily make writing your own texts any easier. Writing a thesis while writing an advice book about how to write a thesis, however, might have contributed to Nygaard's beyond-the-checklist approach. For example, Nygaard's chapter on ethics is particularly helpful in the way it highlights how ethics guidelines and protocols cannot possibly contain all the ambiguities and dilemmas of actual research. 'There might be times when you have to do something that is "unethical" in one way so you can be more ethical in another', Nygaard explains and goes on to illustrate with useful examples (2017: 47). She stresses that 'Even if procedures are clear and you have an obvious set of guidelines to follow, you might not get all the answers you need' (2017: 46). This is, of course, not a novel observation, yet it is a timely reminder that checklists, guidelines, templates, and, indeed, advice books, can be quite deceptive in that they can make difficult intellectual work appear as simple and discrete tasks.

Although the title of the book seems to suggest that the book is for anyone writing a Masters thesis, it is written with a much more specific audience in mind: the target audience are students in the social sciences at institutions located in 'North America, Western Europe, and Australia' (2017: 3). In other words, although not reflected in the book's title, Nygaard is of course aware that there are important disciplinary and institutional contexts that shape the Masters thesis as a genre, and she points this out at various times in the book. Nygaard is also aware that many of the students in her target audience use English as an additional language. This point is 
addressed in a separate sub-chapter, but it is not a central theme. And although I agree with her observation that 'most struggles with writing are related to thinking not to vocabulary' (2017: 72), some might find that this approach glosses over issues of language and the relationship between thinking and vocabulary.

This privileging of thinking over vocabulary is a general feature of the book. While it offers many meaningful and helpful ways to think and to talk about writing, it focuses less on linguistic features and textual moves of the Masters thesis as text. There are some examples that illustrate certain moves, yet most of these are not from authentic texts, but constructed by Nygaard to illustrate particular points. Some of them thus appear a little contrived. The vignettes and questions that accompany each chapter encourage reflection and ways to think about writing, but novice writers may struggle to imagine the words, phrases and linguistic resources that make this kind of writing appear on the page.

To return to my opening question: do we need more advice books? As Kamler and Thomson's analysis suggests, we might at least do well with different kinds of advice book. And that is what this book is, a different sort of book, one that does not present writing as an ability to conform to a checklist, but rather is intended to help students find a sense of purpose about what they want to say and ways to engage with how to say it. I am happy to have it as a resource to recommend to other teachers and writers. 


\section{References}

Harris, J. (2007) Rewriting: How to Do Things with Texts. Logan: Utah State University Press

Harwood, N., \& Petrić, B. (2017) Experiencing Master's Supervision: Perspectives of International Students and Their Supervisors. London: Routledge

Kamler, B., \& Thomson, P. (2008) 'The Failure of Dissertation Advice Books: Toward Alternative Pedagogies for Doctoral Writing'. Educational Researcher 37 (8), 507514

Kamler, B., \& Thomson, P. (2014) Helping Doctoral Students Write: Pedagogies for Supervision. 2nd edn. London: Routledge

Nygaard, L. (2017) Writing Your Master's Thesis: From A to Zen. London: Sage 